\title{
Effects of food quality on the functional ingestion response of the copepod Acartia tonsa
}

\author{
Sarah E. Libourel Houde, Michael R. Roman* \\ Horn Point Environmental Laboratories, University of Maryland, Center for Environmental and Estuarine Studies, \\ PO Box 775, Cambridge, Maryland 21613, USA
}

\begin{abstract}
Effects of food quality on the functional ingestion response of the copepod Acartia tonsa were determined using 3 algal species 6 to $12 \mu \mathrm{m}$ in diameter (dinoflagellate Amphidinium carteri, coccolithophorid Hymenomonas carterae, senescent and actively growing diatom Thalassiosira weissflogii), over a wide range of concentrations. The algal cells were characterized by their contents of carbon, nitrogen, protein, carbohydrate, lipid and chlorophyll $a$ and by dry weight. $A$. tonsa ingestion rates increased to an asymptote and were fit to the Ivlev model without a feeding threshold at low algal concentrations. Maximum ingestion rates of algal cells were inversely proportional to their protein, nitrogen, and carbon content. Maximum ingestion rates of protein and nitrogen increased with increasing cell content of these variables. In contrast, maximum ingestion rates of algal carbon were generally constant with increasing cellular carbon content. The effects of cellular carbohydrate, lipid, and chlorophyll a content on maximum ingestion rates were variable. The rate at which the ingestion of phytoplankton cells approached the maximum ingestion rate increased with greater protein and nitrogen content. Our results suggest that cellular protein and nitrogen content (or factors related to them) are important in regulating $A$. tonsa ingestion rates.
\end{abstract}

\section{INTRODUCTION}

Ingestion rates of copepods are determined by their reaction to ambient particle concentrations, sizes, and biochemical properties. Most research has focussed on the effects of food concentration and size on copepod ingestion rates (see review by Conover 1981) with less emphasis on possible effects of food quality. Copepods can discriminate and selectively ingest phytoplankton over plastic beads (Donaghay \& Small 1979, Huntley et al. 1983, Paffenhöfer \& Van Sant 1985); phytoplankton over detritus (Roman 1977, Roman 1984); and they can differentiate between similar size phytoplankton species (Huntley et al. 1983) as well as phytoplankton of the same species but in different growth states (Ryther 1954, Mullin 1963, Cowles et al. 1987). This ability to discriminate and selectively ingest food particles of greater nutritional quality fits general theories of optimal foraging behavior (Pyke et al. 1977) and can enhance copepod growth rates. For example, ingestion of algal species highest in protein and lipid supported maximum growth and reproduction of Acartia tonsa and the brine shrimp Artemia salina (Cahoon 1981,

\footnotetext{
- Addressee for reprint requests
}

Sick 1976, respectively). This suggests that the amount and quality of food ingested may be a good indicator of zooplankton production rates.

The purpose of this study was to examine the effects of food quality on the functional ingestion response of the euryhaline copepod Acartia tonsa, the dominant copepod species in many temperate and subtropical coastal marine environments (Reeve \& Walter 1977). A. tonsa egg production and ingestion rates respond rapidly to changes in food abundance and food quality (Dagg 1977, Cahoon 1981, Durbin et al. 1983). We conducted short-term ingestion experiments using 3 phytoplankton species of similar size over a wide range of concentrations and food quality. The rate at which ingestion reached saturation levels and the maximum amount of phytoplankton ingested were related to selected biochemical components of the algae in order to examine how food quality affects copepod feeding behavior.

\section{METHODS}

Culture conditions. Acartia tonsa cultures were initiated from copepods collected in the Chesapcake Bay during May and July, 1984. Copepods were main- 
the algal cells were between 6 and $10 \mu \mathrm{m}$. A.c. \#1 had a markedly higher proportion of larger cells relative to A.c. \#2 (Table 3).

Ingestion experiments. Labeled phytoplankton was harvested by gentle filtration over a $3.0 \mu \mathrm{m}$ Nuclepore filter, rinsed and resuspended in filtered seawater. Triplicate samples of labeled algae were filtered onto preweighed, pre-dried $3.0 \mu \mathrm{m}$ membra-fil (Nuclepore) filters, rinsed with ammonium formate, dried and weighed. Fluorescence measurements and microscope counts were taken on both labeled and non-labeled algae. Dry weight and carbon of the non-labeled algae were also measured and compared to the fluorescence and dry weight concentrations of the labeled algae the day of the experiment to calculate test concentrations as $\mu \mathrm{g} \mathrm{Cl}^{-1}$. Each experiment had 7 or 8 food concen-

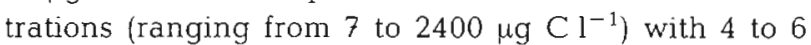
replicates and 3 zero time controls (to correct for adsorption of label to copepods and filters) per treatment.

Ingestion experiments were conducted in 0.51 jars on a rotating wheel (end over end) in the dark for 45 min with 25 Acartia tonsa (adult and Stage $V$ ) per jar. These feeding times are less than the gut retention times of $A$. tonsa determined in dye experiments (Gottfried \& Roman 1983). After incubation, the copepods were collected on $333 \mu \mathrm{m}$ sieves, rinsed with filtered seawater onto preweighed $12 \mu \mathrm{m}$ Nuclepore filters, rinsed with $10 \% \mathrm{HCl}$, and the dry weight and number of copepods determined before isotope analysis. The mean dry weight of $A$. tonsa was $11.14 \mu \mathrm{g}(\mathrm{SE}=0.23)$ individual $^{-1}$. Ingestion rates were converted to $\mu \mathrm{g}$ or cells ingested mg copepod $\mathrm{dw}^{-1} \mathrm{~h}^{-1}$ from algal specific activities and the amount of carbon (C), nitrogen $(\mathrm{N})$, protein (PRO), lipid (LIP), carbohydrate (CHO), chlorophyll a (chl-a), and number of cells $\mathrm{ml}^{-1}$ of labeled algae (Eq. 1) by calculating:

$\mathrm{dpm} \cdot \mathrm{ml} \mathrm{algae}{ }^{-1} \div \mu \mathrm{g}$ algae or \# of cells $\cdot \mathrm{ml}$ algae $^{-1} \div \mathrm{dpm} \cdot \mathrm{mg}$ dry weight copepods ${ }^{-1} \div$ time $=\#$ of cells or $\mu \mathrm{g}$ algae ingested $\cdot \mathrm{mg}$ copepods $\mathrm{dw}^{-1} \mathrm{~h}^{-1}$

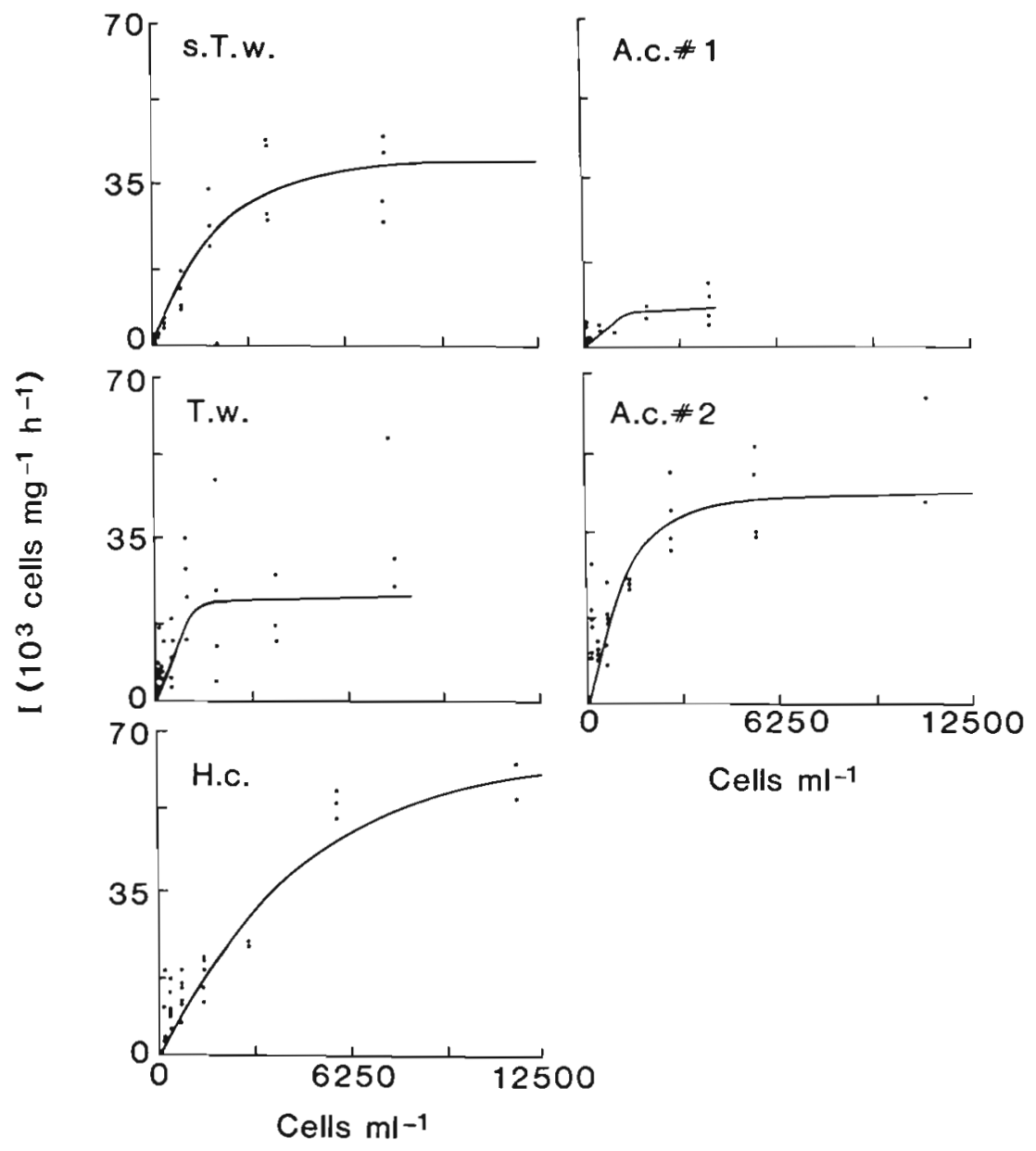

Fig. 1 Acartia tonsa. Functional ingestion response to algal cell density. s.T.W. = senescent Thalassiosira weissflogil, T.W. $=$ actively growing I. weissflogii, H.c. $=$ Hymenomonas carterae, A.c. \#1 = Amphidinium carteri Expt 1, A.c. \#2= A. carteri Expt 2 
Acartia tonsa in this study was $27.73 \% \mathrm{PRO} \mathrm{dw}^{-1}$, $25.38 \% \mathrm{CHO} \mathrm{dw}^{-1}$, and $19.46 \%$ LIP $\mathrm{dw}^{-1}$. Based on these values and $40 \% \mathrm{Cdw}^{-1}$ and $10 \% \mathrm{Ndw}^{-1}$ for $\mathrm{A}$. hudsonica, which is similar in weight to $A$. tonsa (Deason 1980), ingestion rates at saturation concentrations were extrapolated to daily rations of $\mathrm{C}, \mathrm{N}, \mathrm{PRO}$, CHO, LIP, and $d w$ copepod ${ }^{-1} d^{-1}$.

We used the Ivlev equation to fit the ingestion dates:

$$
I=I_{\max } \times\left(1-e^{l-a l p h a \times C_{1}}\right)
$$

where $I=$ ingestion rate $\left(\mu \mathrm{g} \mathrm{mg} \mathrm{dw^{-1 }} \mathrm{h}^{-1}\right.$ or cells $\mathrm{mg}$ $\left.\mathrm{dw}^{-1} \mathrm{~h}^{-1}\right) ; \mathrm{I}_{\max }=$ maximum ingestion rate; $\mathrm{C}=$ food concentration $\left(\mu \mathrm{g} \mathrm{l}^{-1}\right.$ or cells $\mathrm{ml}^{-1}$ ); alpha $=$ rate at which ingestion approaches the maximum ingestion rate. The lower threshold term was excluded from analysis because ingestion was measured at the lowest food concentrations tested. Iteration of the Ivlev equation by the Gauss-Newton method (Hartley 1961) led to convergence of the equation parameters, $I_{\max }$ and alpha, for all food types and biochemical components tested. The model was fit using the NLIN procedure of SAS (Statistical Analysis System).

\section{RESULTS AND DISCUSSION}

The Holling type 2 feeding response (Holling 1965) was observed for all variables of ingestion for all foods tested and was fit well by the Ivlev (1955) equation (Fig. 1 \& 2, Table 4). The ingestion curves with the highest $I_{\max }$ typically had the lowest alpha and the highest food saturation density (food concentration where ingestion rates were within $95 \%$ of $I_{\max }$ Table 4). Conversely, ingestion curves with the highest alpha had the lowest $I_{\text {max. }}$. Fits to the Ivlev model were calculated as $\mathrm{r}^{2}$ and ranged from 0.82 (T.w.) to 0.97 (H.c.). However, the lvlev model underestimated ingestion rates at the lowest particle concentrations that were tested: from 7 to $37 \mu \mathrm{Cl}^{-1}, 2$ to $5 \mu \mathrm{g} \mathrm{Nl} \mathrm{N}^{-1}$, 4 to $15 \mu \mathrm{g} \mathrm{PRO}{ }^{-1}, 3$ to $31 \mu \mathrm{gLPl}^{-1}, 2$ to $5 \mu \mathrm{g} \mathrm{CHOl}{ }^{-1}$, 0.1 to $1.2 \mu \mathrm{g} \mathrm{chl}-\mathrm{al}^{-1}$, and 32 to 187 cells $\mathrm{ml}^{-1}$. This underestimate may be a function of the large error associated with alpha (Table 4 ) and because the model heavily weights data at high food levels relative to low Ievels. However, in coastal areas where Acartia tonsa is abundant from early summer through fall, ambient

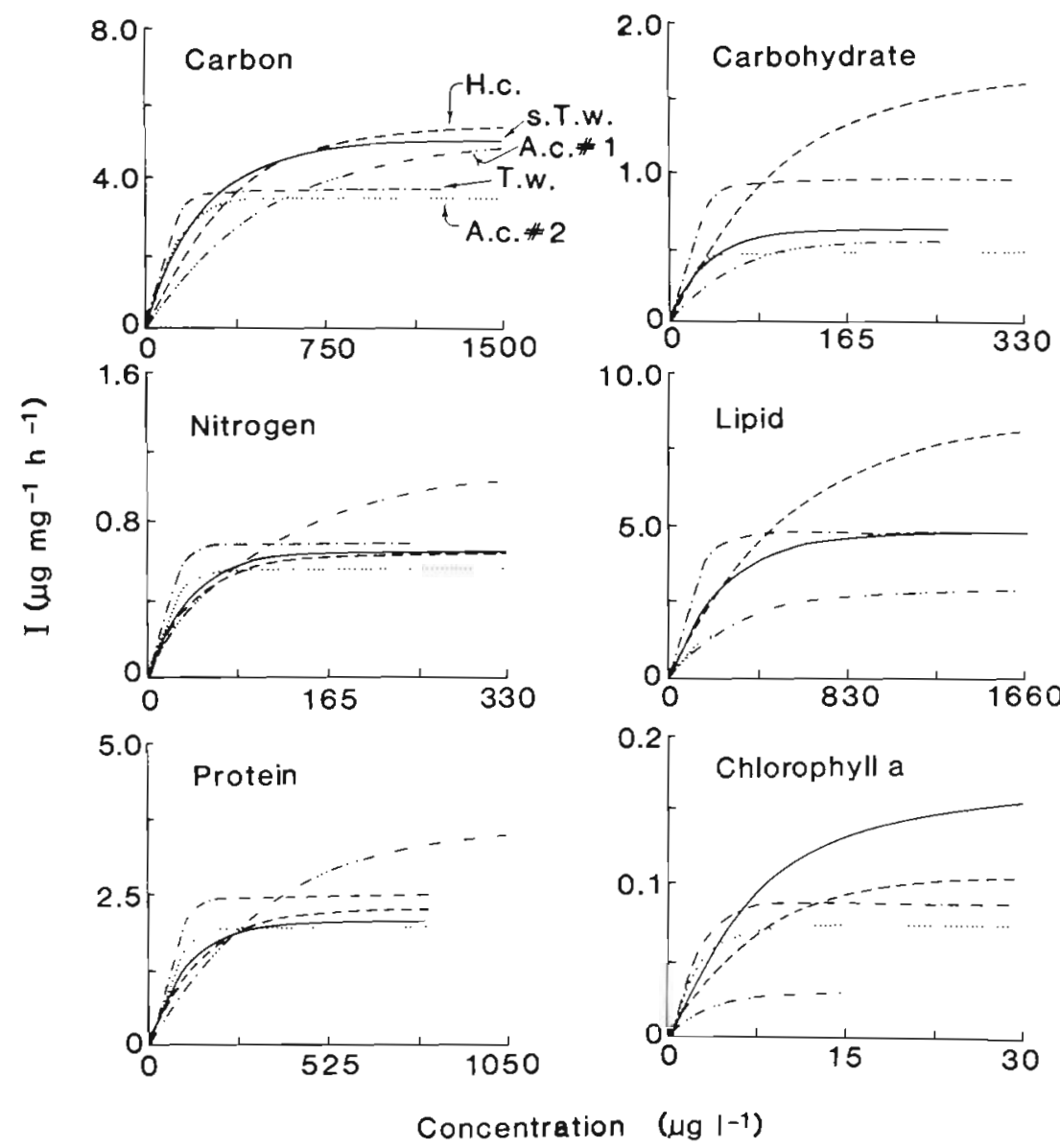

Fig. 2. Acartia tonsa. Functional ingestion response to algal carbon, nitrogen, protein, carbohydrate, lipid and chlorophyll a. Algae as in Fig. 1. Ingestion rates at the highest concentrations for some food types and biochemical components are not plotted, so that the scale on $X$-axis could be expanded to more easily examine ingestion at the lowest food concentration 
Table 4. Acartia tonsa ingestion rates calculated from Eq. (2). $\mathrm{I}_{\max }=\mu \mathrm{g}$ or cells $\mathrm{mg}^{-1} \mathrm{~h}^{-1}$ ( \pm asymptotic $95 \%$ confidence interval); alpha $=\mathrm{mg}^{-1} \mathrm{~h}^{-1}( \pm 95 \%$ confidence interval $) ; \mathrm{r}^{2}=$ coefficient of determination; $\mathrm{S}=$ saturation concentration in $\mu \mathrm{g} \mathrm{l}^{-1}$ or cells $\mathrm{ml}^{-1}$. Numbers of samples were $38,36,38,43$ and 35 for s.T.w., T.W., A.c.\#1, A.c.\#2, and H.c., respectively

\begin{tabular}{|c|c|c|c|c|c|}
\hline & Component & $I_{\max }( \pm 95 \% \mathrm{CI})$ & alpha $( \pm 95 \%$ CI $)$ & $r^{2}$ & $\mathrm{~S}$ \\
\hline s.T.w. & $\mathrm{C}$ & $5.0456(.6615)$ & $.0041(.0014)$ & .9283 & 731 \\
\hline$T . w$. & & $3.6654(.7856)$ & $.0122(.0076)$ & .8205 & 245 \\
\hline A.C.\# 1 & & $5.1379(1.2135)$ & $.0020(.0012)$ & .8294 & 1490 \\
\hline A.c.\#2 & & $3.5185(.3909)$ & $.0090(.0031)$ & .9260 & 332 \\
\hline H.c. & & $5.4088(.5326)$ & $.0029(.0007)$ & 9661 & 1032 \\
\hline s.T.w. & $N$ & $.6399(.0758)$ & $.0302(.0096)$ & .9415 & 99 \\
\hline T.w. & & $.6812(.1461)$ & $.0657(.0409)$ & .8201 & 46 \\
\hline A.c.\#1 & & $1.0867(.2568)$ & $.0095(.0058)$ & .8292 & 315 \\
\hline A.c.\#2 & & $.5971(.0679)$ & $.0523(.0186)$ & .9231 & 57 \\
\hline H.c. & & $.6217(.0707)$ & $.0250(.0062)$ & .9657 & 120 \\
\hline s.T.w. & PRO & $2.0546(.2437)$ & $.0094(.0030)$ & .9413 & 319 \\
\hline$T . w$. & & $2.4931(.5342)$ & $.0180(0.111)$ & .8206 & 166 \\
\hline A.C.\#1 & & $3.6210(.8516)$ & $.0029(.0018)$ & .8301 & 1044 \\
\hline A.c. \#2 & & $1.9776(.2194)$ & $.0160(.0056)$ & .9262 & 187 \\
\hline H.c. & & $2.2320(.2194)$ & $.0070(.0017)$ & .9659 & 427 \\
\hline s.T.W. & $\mathrm{CHO}$ & $.6501(.0770)$ & $.0297(.0094)$ & .9415 & 101 \\
\hline T.W. & & $.9548(.2044)$ & $.0469(.0289)$ & .8205 & 64 \\
\hline A.C.\#1 & & $.5418(.1267)$ & $.0193(.0118)$ & .8308 & 155 \\
\hline A.c. $\# 2$ & & $.4573(.0499)$ & $.0705(.0238)$ & .9278 & 42 \\
\hline H.c. & & $1.6973(.1672)$ & $.0092(.0023)$ & .9659 & 325 \\
\hline s.T.w. & LIP & $4.7978(.5685)$ & $.0040(.0013)$ & .9415 & 749 \\
\hline T.w. & & $4.8000(1.0297)$ & $.0093(.0058)$ & .8205 & 321 \\
\hline A.c.\#1 & & $2.9598(.6994)$ & $.0035(.0021)$ & .8292 & 858 \\
\hline A.c.\#2 & & $1.5902(.1718)$ & $.0199(.0070)$ & .9251 & 151 \\
\hline H.C. & & $8.6145(.8499)$ & $.0018\{.0004\}$ & .9659 & 1655 \\
\hline s.T.w. & Chl-a & $.1595(.0189)$ & $1211(.0383)$ & .9417 & 25 \\
\hline T.W. & & $.0882(.0189)$ & $.5100(.3105)$ & .8205 & 6 \\
\hline A.c.\#1 & & $.0292(.0068)$ & $.3612(.2205)$ & .8236 & 8 \\
\hline A.c. \#2 & & $.0731(.0081)$ & $.4287(.1515)$ & .9237 & 7 \\
\hline H.C. & & $1059(.0104)$ & $.1466(.0364)$ & .9665 & 20 \\
\hline s.T.W. & Cells & 39861 (4713) & $.0005(.0002)$ & .9417 & 6241 \\
\hline T.w. & & $23515(5142)$ & $.0020(.0013)$ & .8229 & 1468 \\
\hline A.c. \#1 & & $8976(2120)$ & $.0012(.0007)$ & .8294 & 2598 \\
\hline A.c.\#2 & & $43884(4886)$ & $.0007(.0002)$ & .9258 & 4160 \\
\hline H.C. & & $66175(6547)$ & $.0002(.0001)$ & .9657 & 12482 \\
\hline
\end{tabular}

concentrations generally exceed these low values. For example, summer and fall particulate concentrations range from 722 to $4621 \mu \mathrm{g} \mathrm{Cl}^{-1}$ and 62 to $545 \mu \mathrm{g} \mathrm{Nl} \mathrm{Nl}^{-1}$ in the upper Chesapeake Bay, Maryland, USA (Malone et al. 1986) and from 450 to $3388 \mu \mathrm{g} \mathrm{Cl}^{-1}, 50$ to $200 \mu \mathrm{g}$ $\mathrm{Nl}^{-1}$, and 2 to $52 \mu \mathrm{g}$ chl-a $1^{-1}$ in Narragansett Bay, Rhode Island, USA (Durbin et al. 1983).

The 2 experiments using the dinoflagellates had large differences in both the biochemical content of the algae and ingestion parameters by Acartia tonsa. For each feeding experiment, filtrations for biochemical analysis were done from 1300 to $1400 \mathrm{~h}$ and experiments were conducted between 1400 and $1730 \mathrm{~h}$. Thus, it was assumed that A.C. \#1 and A.C. \#2, both grown under identical conditions, would have similar cell characteristics. However, A.c. \#1 cells were larger than A.C. \#2 (Table 3) and thus hat higher cellular concentrations of carbon, nitrogen, protein, lipid and carbohydrate (Table 2). Olson \& Chisholm (1983) have shown that nutrient-replete cultures of $A$. C. grown on a 14:10 light:dark cycle have synchronized cell division that begins at the beginning of the dark period. It is possible that the cell cycle of $A$. c. became increasingly offset while acclimating to the culture conditions used in this study or that culture dilution rates differed between experiments, causing cell division to occur later in the dark cycle. This may have resulted in more small cells (or fewer doublet cells) being present when the A.c. \#2 experiment was conducted. It is also possible that A.C. \#2 exhibited periods of no division as observed by Olson \& Chisholm (1983).

Maximum cell ingestion rates were inversely proportional (i.e. a negative exponential relation) to cellular protein, nitrogen, and carbon content, while the 

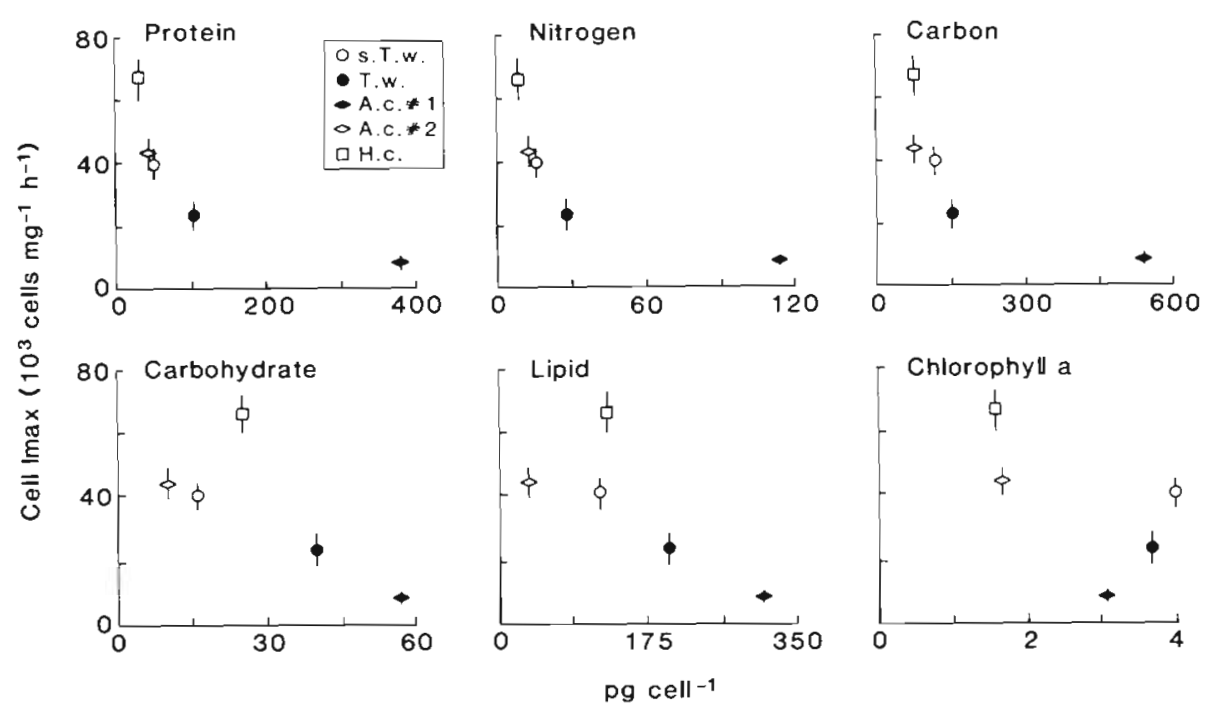

Fig. 3. Relation between maximum cell ingestion rates and cellular biochemical content. Maximum ingestion rates plotted with $95 \%$ confidence limits

relations between cell $I_{\max }$ and carbohydrate, lipid, and chlorophyll-a cellular content were unclear (Fig.3). Ingestion of H.c. and A.c. \#2, which were lowest in nitrogen and protein, resulted in the highest maximum ingestion rates of cells while ingestion of A.c. \#1, which was highest in $N$ and protein, resulted in the lowest maximum cell ingestion rate. However, the particle capture efficiency of Acartia (based on intersetule distances) is greater on particles larger then $8 \mu \mathrm{m}$ in diameter relative to smaller particles (Nival \& Nival 1976, Donaghay \& Small 1979, Bartram 1980). Thus, A. C. \# 1 may have been captured more efficiently than A. C. \#2 because of its larger cell size (Table 3), which may explain the higher alpha observed for $A$. $c$. \# 1 cell ingestion compared to A.c. \#2 (Table 4). Maximum cell ingestion of $A . C$. \#1 occurred at a lower cell density than A.C. \#2. This agrees with Frost (1972) who found that maximum ration is attained at lower concentrations of larger cells compared to smaller cells.

It has been shown that zooplankton ingest actively growing cells at a faster rate than senescent or slowly growing cells (Rhyther 1954, Mullin 1963, Cowles et al. 1987). In this study, T.w. had a higher cellular content of all measured biochemical components except chl-a than S.T.W. Maximum ingestion rates of S.T.W. C, chl-a, and cells were higher than T.W. (Table 4). Maximum ingestion rates of all biochemical components of $T$. $w$. always occurred at lower concentrations that the same components of S.T.w. because at cell concentrations lower than the critical or saturation concentration, Acartia tonsa ingested more actively growing $T . W$.

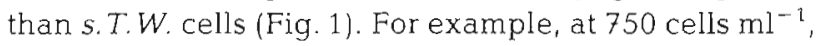
A. tonsa ingested 2035 cells copepod ${ }^{-1} \mathrm{~h}^{-1}$ of T.W. and 1389 cells copepod ${ }^{-1} h^{-1}$ of s.T.W.

If protein and amino acids act as phagostimulants as suggested by Poulet \& Ouellet (1978) and Cowles et al. (1987), one would expect that the algal cells highest in protein and $\mathrm{N}$ (or those leaking the most amino acids) would be ingested at a rate which rapidly approaches $I_{\max }$ (i.e. high alpha values). Our data show that the alphas for cell ingestion increased with greater cellular protein, nitrogen, and carbon content while the relationships between alpha and cellular carbohydrate, lipid, and chlorophyll a content were not clear (Fig. 4). If we exclude A.c. \#1, which was significantly larger than other algae (Table 3 ), the correlations $\left(r^{2}\right)$ of cell alpha to the biochemical composition of the cells were protein $=0.96$, nitrogen $=0.98$, carbon $=0.68$, carbohydrate $=0.52$, lipid $=0.38$, chlorophyll $a=0.26$. Thus for cells of similar size (or equal capture efficiency), protein content may be the best 'predictor' of cell ingestion rate below $I_{\max }$. Because of this higher ingestion the density of cells required by the copepod to attain $I_{\max }$ was inversely proportional to the nitrogen and protein content of the algae $\left(\mathrm{r}^{2}=0.71\right.$ and 0.61 respectively); less for carbon $\left(r^{2}=0.42\right)$, bur not for carbohydrate or cellular lipid composition $\left(r^{2}=0.05\right.$ and 0.02 , respectively).

The maximum ingestion rates of algal nitrogen and protein increased with increasing cellular nitrogen and protein, respectively, while maximum carbon ingestion rates were generally constant with increasing cellular carbon content (Fig. 2, Table 4). the specific daily rations which Acartia tonsa consumed (at $\mathrm{I}_{\max }$ ) of the various biochemical constituents appear low in comparison to previously published ingestion rates. For example, A. hudsonica feeding on Skeletonema costatum consumed a maximum daily ration of $660 \% \mathrm{C}$ and $250 \% \mathrm{~N}$ (Deason 1980). The small copepod species Paracalanus parvus feeding on Thalassiosira weiss- 


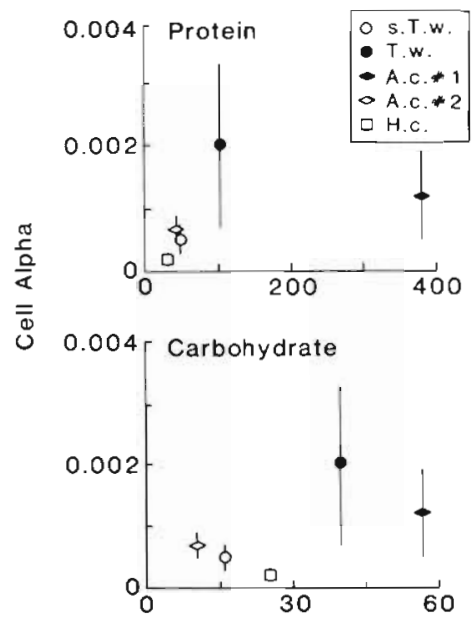

Fig. 4. Relation between alpha from cell ingestion and cellular biochemical content. Maximum ingestion rates plotted with $95 \%$ confidence limits flogii had daily rations of $360 \% \mathrm{C}$ and $150 \% \mathrm{~N}$ (Checkley 1980). Generally, however, maximum daily carbonspecific ration of Acartia species is < $100 \%$ (Petipa 1966, Vargo 1976, Roman 1977). The low values we obtained may be characteristic of the species or may be the result of extrapolation of our short-term ingestion measurements to daily rates. A. tonsa may show enhanced feeding rates in the dark (Stearns 1986). Although our grazing measurements were run in opaque jars, they were conducted during the day. Thus if A. tonsa exhibits an endogenous feeding behavior cued to photoperiod, extrapolated short-term feeding experiments, even though they were conducted in the dark, would underestimate daily rations. In addition, because the algae fed to $A$. tonsa were $<12 \mu \mathrm{m}$, their filtration efficiency may be $<60 \%$ (Bartram 1980). Thus, their daily rations might be expected to be lower than found in studies using larger cells (i.e. S. costatum in Deason 1980) and for the same size algal cells fed to copepods which are more efficient at capturing smaller cells than A. tonsa (i.e. P. parvus in Checkley 1980).

A unique aspect of this study ist that ingestion rates of the various algae were measured not only in terms of carbon, chlorophyll $a_{1}$ and cells but also in terms of nitrogen, protein, carbohydrate, and lipid. Our results suggest that Acartia tonsa may regulate its maximum ingestion rate of cellular protein, nitrogen, and carbon. Note that $I_{\max }$ for protein, nitrogen and carbon for the 5 algal treatments varied by less than a factor of 2 whereas $I_{\max }$ of carbohydrate, lipid and chlorophyll a varied by more than 3 -fold (Table 4 ). A. tonsa might detect differences in cellular protein and nitrogen levels before ingestion by the amount of amino acids in the zone around the algae. This behavior may have resulted in the higher alphas for cell-ingestion which we observed for algae which had higher cellular contents of protein and nitrogen. Then copepods may also respond to differences in algal biochemistry after ingestion by becoming satiated sooner on protein and nitrogen-rich algae. It ist interesting to note that the copepod Eucalaus pileatus became saturated at 10 to $20 \mu \mathrm{g} \mathrm{Nl}^{-1}$ when feeding on the diatom Rhizosolenia alta, but not a similar nitrogen concentrations of fecal pellets (Paffenhöfer \& Van Sant 1985). In our experiments, A. tonsa ingested more algal cells which were low in protein, nitrogen, and carbon in order to maximize its intake of these variables. Thus $I_{\max }$ was inversely proportional to the protein content of the algae $\left(\log I_{\max }=4.7440-0.0022\right.$ protein $\mathrm{cell}^{-1}, \mathrm{r}^{2}=$ 0.90). High and variable maximum ingestion rates of carbohydrate, lipid, and chlorophyll a may be a consequence of $A$. tonsa ingesting more of the cells lowest in protein and nitrogen in order to satisfy ist nutritional requirements.

There have been several attempts to model the feeding behavior of copepods (e.g. Steele \& Frost 1977 , Lehman 1976, Bartram 1980). These models estimate copepod ingestion rates from the concentration and size composition of the phytoplankton community. Our results demonstrate that the biochemical composition of the algae also can regulate copepod ingestion rates. Thus parameters such as $\mathrm{C} / \mathrm{N}$ and protein/carbon ratio or data on protein cell ${ }^{-1}$ or nitrogen cell ${ }^{-1}$ obtained using flow-cytometry (i.e. Cowles et al. 1987) in conjunction with copepod feeding experiments may be used to better predict the utilization rate of phytoplankton in situ.

Algal protein and nitrogen may be the most important 'cues' that regulate copepod ingestion rate (Roman 1983). One might speculate that at the beginning of a 


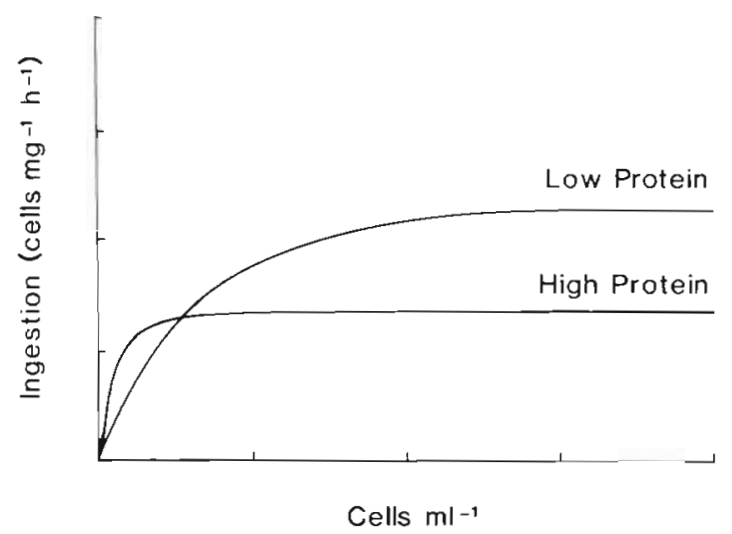

Fig. 5. Acartia tonsa. Idealized functional response curve for cell ingestion: low vs high protein algae

Table 5. Acartia tonsa. Daily ration at $I_{\max }$. Values expressed as $\%$ body $\mathrm{C}, \mathrm{N}, \mathrm{PRO}, \mathrm{CHO}, \mathrm{LIP}$, and $\mathrm{dw} \mathrm{d}^{-1}$

\begin{tabular}{lrrrrr|}
\hline & s.T.W. & T.w. & A.c.\#1 & A.c.\#2 & H.C. \\
\hline C & 30.27 & 21.99 & 30.83 & 21.11 & 32.45 \\
N & 15.36 & 16.35 & 26.08 & 14.33 & 14.92 \\
PRO & 17.78 & 21.58 & 31.34 & 17.12 & 19.32 \\
CHO & 6.15 & 9.02 & 5.12 & 4.32 & 16.05 \\
LIP & 59.17 & 59.20 & 36.50 & 19.61 & 106.24 \\
dw & 64.10 & 28.44 & 20.31 & 43.08 & 45.10 \\
\hline
\end{tabular}

phytoplankton bloom, when algae are high in protein due to the availability of inorganic nutrients, copepods would reach their maximum ingestion rate at low cell concentrations but at a fast rate, i.e. with a high alpha (Fig. 5). As inorganic nutrients are depleted and the phytoplankton have less protein cell ${ }^{-1}$, maximum copepod ingestion rate would occur at a higher cell concentration but with a lower alpha than earlier in the bloom. Therefore, during the early bloom less cells are eaten per copepod and more cells are left to divide and grow. Later in the bloom when algal cells are lower in protein, the copepods may ingest more algal cells per individual to satisfy their protein requirements. A reduction in phytoplankton abundance may reduce competition between algae for the remaining nutrients. Enhanced grazing on low protein algae might also result in less phytoplankton in the water column allowing light to penetrate deeper, extending primary production in the water column. By responding to the protein or nitrogen content of algae, copepod feeding could thus regulate or contribute to fluctuations in phytoplankton productivity and standing stock.

A.cknowledgements. This research was supported by NSF grant OCE-8116585 to M. R. Roman. It was conducted in partial fulfillment towards S. Houde's Master's degree at the University of Maryland. We thank D. Allan, T Jones, T
Malone, M. Mullin and J. White for reviewing an early version of the manuscript. P. Chisholm supplied the algal cultures. K. Ashton, S.-Y Chao, A. Gauzens and S. Papineau provided technical assistance.

\section{LITERATURE CITED}

Barnes, H., Blackstock, J. (1973). Estimation of lipids in marine animals and tissue: detailed investigation of the sulphovanillan method for 'total' lipids. J. exp. mar. Biol. Ecol. 12: $103-118$

Bartram, W. C. (1980). Experimental development of a model for the feeding of neritic copepods on phytoplankton. J. Plankton Res. 3: 25-51

Cahoon, L. B. (1981). Reproductive response of Acartia tonsa to variations in food ration and quality. Deep Sea Res. 28: 1215-1221

Checkley, D. M. (1980). The egg production of a marine planktonic copepod in relation to its food supply: laboratory studies. Limnol. Oceanogr. 25: 430-446

Conover, R. J. (1981). Nutritional strategies for feeding on small suspended particles. In: Longhurst, A.R. (ed.) Analysis of marine ecosystems. Academic Press, New York, p. 363-396

Cowles, T. J., Olson, R. J., Chisholm, S. W. (1987). Food selection by copepods: discrimination between cells on the basis of food quality. Mar. Biol. (in press)

Dagg, M. (1977). Some effects of patchy food environments on copepods. Limnol. Oceanogr. 22: 99-107

Deason, E. E. (1980). Grazing of Acartia hudsonica (A. clausi) on Skeletonema costatum in Narragansett Bay (USA): influence of food concentration and temperature. Mar. Biol. 60: 101-113

Donaghay, P. L., Small, L. F. (1979). Food selection capabilities of the estuarine copepod Acartia tonsa. Mar. Biol. 52: $137-146$

Dubois, M., Gilles, K. A., Hamilton, J. K., Rebers, P. A., Smith F. (1956). Colorimetric method for the determination of sugars and related substances. Analyt. Chem. 28: 350-356

Durbin, E. G., Durbin, A. G., Smayda, T. J., Verity, P. G (1983). Food limitation of production by adult Acartia tonsa in Narragansett Bay, Rhode Island. Limnol. Oceanogr. 28: $1199-1213$

Frost, B. W. (1972). Effects of size and concentration of food particles on the feeding behavior of the marine planktonic copepod Calanus pacificus. Limnol. Oceanogr 17: 805-815

Goldman, J. C., Oswald, W. J., Jenkins, D. J. (1974). The kinetics of inorganic carbon limited algal growth. J. Wat Pollut. Control Fed. 46: 554-574

Gottfried, M., Roman, M. R. (1983). Ingestion and incorporation of coral-mucus detritus by reef zooplankton. Mar. Biol 72: $211-218$

Guillard, R. L. (1975). Culture of phytoplankton for feeding marine invertebrates. In: Smith, W. L., Chanley, M. H. (ed.) Culture of marine invertebrate animals. Plenum Press, New York, p. 29-60

Guillard, R. L., Keller, M. D. (1984). Culturing dinoflagellates. In: Spector, D.L. (ed.) Dinoflagellates. Academic Press, New York, p. 391-442

Hartley, H. O. (1961). The modified Gauss-Newton method of fitting non-linear regression functions by least squares. Technometrics 3: 269-280

Hartree, E. F. (1972). Determination of protein: a modification of the Lowry method that gives a linear photometric response. Analyt. Biochem. 48: 422-427 
Holling, C. S. (1965). The functional response of predators to prey density and its role in mimicry and population regulation. Mem. Entomol. Soc. Can. 45: 3-60

Huntley, M. E., Barthel, K. G., Star, J. L. (1983). Particle rejection by Calanus pacificus: discrimination between similarly sized particles. Mar. Biol. 74: 151-160

Ivlev, V.S. (1955). Experimental ecology of the feeding of fishes. Yale Univ. Press, New Haven (Translated, D. Scott, 1961)

Lehman, J. T (1976). The filter feeder as an optimal forager and the predicted shapes of feeding curves. Limnol. Oceanogr. 21: 501-516

Malone, T C., Kemp, W. M., Ducklow, H. W., Boynton, W. R., Tuttle, J. H., Jonas, R. B. (1986). Lateral variation in the production and fate of phytoplankton in a partially stratified estuary. Mar. Ecol. Prog. Ser. 32: 149-160

Mayzaud, P., Poulet, S. A. (1978). The importance of the time factor in the response of zooplankton to varying concentrations of naturally occurring particulate matter. Limnol. Oceanogr. 23: 1144-1154

Mullin, M. M. (1963). Some factors affecting the feeding of marine copepods of the genus Calanus. Limnol. Oceanogr. 8: $239-250$

Nival, P., Nival, S. (1976). Particle retention efficiencies of a herbivorous copepod. Acartia clausi (adult and copepodite stages): effects on grazing. Limnol. Oceanogr. 21: 24-38

Olson, R. J., Chisholm, S. W. (1983). The effects of photocycles and periodic ammonia supply on three marine phytoplankton species. I. Cell division patterns. J. Phycol. 19: 522-528

Paffenhöfer, G.-A., Van Sant, K. B. (1985). The feeding response of a marine planktonic copepod to quantity and quality of particles. Mar. Ecol. Prog. Ser. 27: 55-65

Petipa, T. S. (1966). Relationship between growth, energy metabolism and ration in Acartia clausi Giebri. In: Physiology of marine animals. Akad. Nauk. SSSR, Oceanographical Commission, Moscow, p. 82-91

Poulet, S. A., Oullet, G. (1982). The role of amino acids in the chemosensory swarming and feeding of marine copepods. J. Plankton Res 4: 341-361

Pyke, G. H., Pulliam, H. R., Charnov, E. L. (1977). Optimal foraging: a selective review of theory and test. $Q$. Rev. Biol. 52: $137-154$

Reeve, M. R., Walter, M. A. (1977). Observations on the existence of a lower threshold and upper critical food concentrations for the copepod Acartia tonsa Dana. J. exp. mar. Biol. Ecol. 29: 211-221

Roman, M. R. (1977). Feeding of the copepod Acartia tonsa on the diatom Nitzschia closterium and brown algae (Fucus vesiculosus) detritus. Mar. Biol. 42: 149-155

Roman, M. R. (1983). Nitrogenous nutrition of marine invertebrates. In: Carpenter, E. J., Capone, D. G. (ed.) Nitrogen in the marine environment. Academic Press, New York, p. $347-383$

Roman, M. R. (1984). Utilization of detritus by the copepod, Acartia tonsa. Limnol. Oceanogr. 29: 949-959

Ryther, J. H. (1954). Inhibitory effects of phytoplankton upon feeding of Daphnia magna with reference to growth, reproduction, and survival. Ecology 35: 522-533

Sick, L. V (1976). Nutritional effect of five species of marine algae on the growth, development, and survival of the brine shrimp Artemia salina. Mar. Biol. 35: 69-78

Stearns, D. E. (1986). Copepod grazing behavior in simulated natural light and its relation to nocturnal feeding. Mar. Ecol. Prog. Ser 30:65-76

Steele, J. H., Frost, B. W. (1977). The structure of plankton communities. Phil. Trans. R. Soc. 280:485-534

Vargo, G. A. (1976). The influence of grazing and nutrient excretion by zooplankton on the growth and production of the marine diatom Skeletonema costatum (Greville) Cleve, in Narragansett Bay. Doctoral dissertation, Univ. of Rhode Island, Kingston

Yentsch, C. S., Menzel, D. W. (1963). A method of determination of phytoplankton chlorophyll and phaeophytin by fluorescence. Deep Sea Res. 10: 221-231

This article was presented by Professor K. R. Tenore; it was accepted for printing on June 29, 1987 